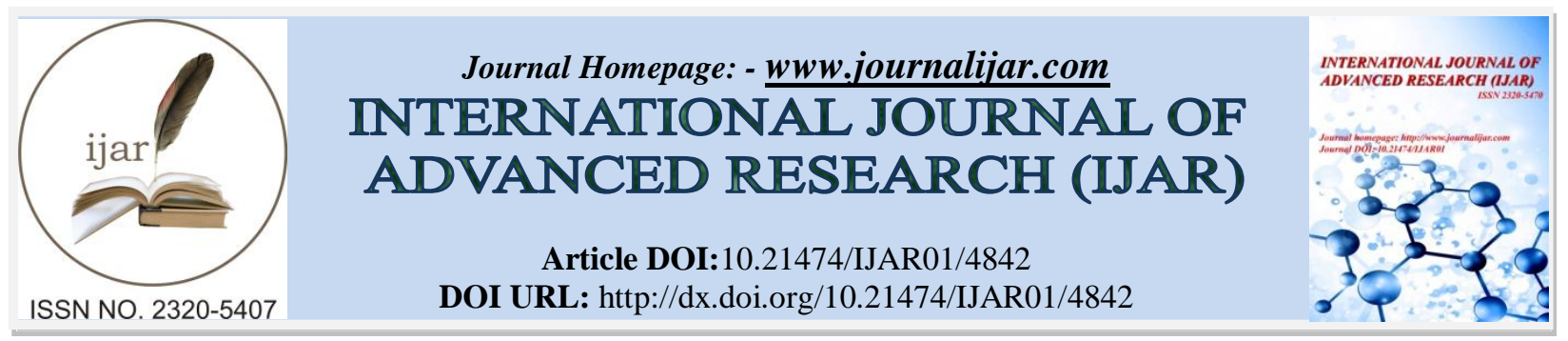

RESEARCH ARTICLE

\title{
INDIGENOUS OPINIONS FOR ACHIEVING JUSTICE AND ENDURING PEACE IN THE NIGER DELTA, NIGERIA.
}

\section{*Johnson Egbemudia Dudu Ph.D ${ }^{1}$ and Imongan Ernest Omokhoa ${ }^{2}$.}

1. Senior Research Fellow/Acting Director of Research: Centre for Population and Environmental Development, Benin City, BS-1 and SM-2, Ugbowo Shopping Complex, EDPA Housing Estate, P. O. Box 10085, Ugbowo Post Office, Benin City, Edo State, Nigeria.

2. Research Officer: Centre for Population and Environmental Development, Benin City, BS-1 and SM-2, Ugbowo Shopping Complex, EDPA Housing Estate, P. O. Box 10085, Ugbowo Post Office, Benin City, Edo State, Nigeria.

\section{Manuscript Info}

Manuscript History

Received: 14 May 2017

Final Accepted: 16 June 2017

Published: July 2017

Key words:-

Indigenous Opinions,

Justice, Peace, Niger Delta, Nigeria.

\section{Abstract}

Objective: The Niger Delta area of Nigeria for decades after oil exploration still remained one of the least developed regions in the country. Several attempts have been made by the Federal Government of the nation to bring about peace in the region. Despites the various developmental initiatives put in place by the Federal Government and the oil companies, restiveness and agitations by the people in the area have continued unabated. Thus, this study critically examined the indigenous opinions for achieving justice and enduring peace in the Niger Delta, Nigeria.

Design: The study was carried out using in-depth interviews and focus group discussions to generate relevant data for the research with 75 persons as participants in the in-depth interview and 40 participants who took part in the focus group discussions in four Local Government Areas of Bayelsa State, Nigeria.

Result: Results from the study revealed that the desired expectations of the people in the region which will bring about justice and peace include: institutional/constitutional economic/inclusiveness participation demands; Infrastructural demands and Oil companies/Federal Government behavioral Change demands.

Recommendations: The paper recommends that in order to achieve enduring peace in the region, demands of the people should be taken seriously by the Federal Government of Nigeria and the International Oil Companies with an action plan immediately put in place to addressing the aspirations of the people of Niger Delta if justice and peace is to be part of the region

Copy Right, IJAR, 2017,. All rights reserved.

\section{Introduction:-}

Nigeria is one of the major countries in Africa that is endowed with abundance of natural resources. She is a major exporter and a player in the petroleum industry. Presently, the bulk of mineral wealth of the nation is gotten from the Niger Delta area which makes it a major hub of economic activities as the Nigerian Government and other countries

Corresponding Author:- Johnson Egbemudia Dudu.

Address:- Senior Research Fellow/Acting Director of Research: Centre for Population and 1313 
of the world depend on it resources for their continue existence (Omuta; 2014 ). Therefore, it is unarguably that the Niger Delta is the richest and most endowed region in Nigeria. The region is made up of about 70 per cent of the national wealth comprising off - shore oil well as well as on - shore facilities that are located within the region (Ikelegbe, 2010). Also, the oil resources and infrastructure are in about 1,500 communities in the region where they produce the majority of the oil and gas wealth of the country (Ikelegbe, 2010). Oil is very important to the economy of Nigeria. It can be best appreciated by the fact that by early 2000, oil and gas accounted for about $98 \%$ of all export earnings, $83 \%$ of Federal Government revenue, 95\% of foreign exchange earnings and more than 14 per cent of its Gross Domestic Product (Omuta, 2014). Oil has helped and continued to be the driver of economic development in the country. The 36 states, including the Federal Capital Territory, get their monthly allocation from the Federal Government Revenue, the bulk of which is derived from oil resources in the Niger Delta.

While development is promoted by oil wealth, the indigenous people (Niger Deltans) who leave in the oil bearing localities have been dealing with the consequences of the endless exploitations. The exploration is certainly of no significant benefit to the people of the Niger Delta taking into consideration the amount of wealth accruing from the region as it has rather brought about some negative and unpalatable effects to the people of Niger Delta region (Nwankwo, 2015). However, in spite of the wealth gotten from the Niger Delta the people still remain poor. This deplorable condition of the indigenous people due to the persistence oil exploration and environmental degradation, in turn, had brought the feeling of injustice and agitations such as the AdakaBoro's struggle of 1967; mass demonstration in the 1990s involving mass protest followed by violent attacks on personal and oil installations, hostage taking amongst others (Tonwe, \&Aghedo, 2013). This period marked a turning point in highlighting problems of environmental governance, economic marginalization and failing corporate social responsibility in the volatile region in the Niger Delta. The conflict became highly volatile and militarized with emergence of several militant groups such as the Movement for the Emancipation of the Niger Delta People (MEND), the Niger Delta People Volunteer Force (NDPF) and many others. These groups from the Niger Delta most especially in the region largest ethnic group the Ijaw, initiated 'Operation Climate Change' which led violent conflicts between them and the Nigerian armed forces that eventually metamorphosed into militias (Aghedo, 2013; Atumah, 2015). The situation became deplorable and devastated as the militants force changed the socio-economic and political tone with devastating effect not only to the region but to the nation at large, and beyond as it negatively affected oil production and the economy (Ering, Bassey\&Odike, 2013; Okonta, 2013). Despite all the agitations, the situation of Niger Delta had remained unchanged. This situation has led to greater emergence of more militants. The inhabitants living in this area felt deprived and marginalized as their resources are exploited without compensation or any meaningful development for the resources within their domain.

Stemming from the various agitations and uprising, the Federal Government initiated various moves to compensate and make life better for the people of the Niger Delta by putting several measures in place to address observed challenges such as: Setting up several intervention programs notably, the Niger Delta Developmental Board (NDDB), Niger Delta Basin Development Authority (NDBDA), Oil Mineral Producing Areas Development Commission, (OMPADEC) and the Niger Delta Development Commission (NDDC) (Ibude, 2011; Tonwe\&Aghedo, 2013; Jack-Akhigbe, 2013). And recently, the Federal Government launched the Presidential Amnesty Program (PAP) entailing among other things the pardon for militants that have been involved in the Niger Delta crisis (Agbebedia, 2014). All the above mentioned intervention programs could not bring about the much needed development, and could not yield the much desire results. The agitations in the region continued, leading to the emergence of the Niger Delta Avengers (NDA). This new militant group (NDA) had been attacking and vandalizing production pipeline, forcing companies such as Shell Petroleum Development Company (SPDC), Chevron Nigeria Limited (CNL), Nigerian Agip Oil Company (NAOC) and others to shut down production operations as a way to press home their demands. All the attempts by the current government of President Mohamadu Buhari for the NDA to come to the negotiation table have fallen on deaf ears and Nigeria oil production has continued to decline leading to recession and economic down turn (Amaize et al, 2016).

It is puzzling, that in spite of the Federal Government attempts at pacifying the region, through the various mentioned interventions, the agitations by the people of the region have continued to increase. Hence, if the various government efforts and interventions did not bring the needed peace or did not meet the yearning of the people from the region; what then are the expectations of the Niger Delta people from the Federal Government of Nigeria as to guarantee justice and peace in the region? It is the goal of this study to provide answers to the above conundrum. 


\section{Methods:-}

\section{Research Design, Sampling and Recruitment:-}

The study adopted qualitative techniques such as in-depth interview and focus group discussions (FGDs) to generate relevant data for the research. The in-depth interviews involved interviewing key personnel of institutions and some social activists who were opinion leaders. The study took place in 4 (four) Local Government Areas (LGAs) of Bayelsa State that have experienced militants activities over time such as: Brass, Ekeremor, Sagbama and Southern Ijaw LGAs. The study took place from June 2015 to March, 2016. A systematic sampling method was adopted to select the housing units where the household interviews were conducted. The study began with contacts setting and visits to relevant stakeholders and authorities to inform them of the purpose and permission to start the study including Development Committees, Local Government Authorities, State Government and some Federal Agency responsible for Amnesty.

\section{Interviews and Focus Group Discussions (FGDs):-}

In all, 75 in-depth interviews were held with different stakeholders on different issues relating to the Niger Delta Question, amnesty and peace with each ward unit contributing at least an opinion leader to the interview. Regarding FGDs, four of them were held including one each in Twon-Brass, Ekeremor, Sagbama and Oporoma -the headquarters of Brass, Ekeremor, Sagbama and Southern Ijaw LGAs, respectively. In all, 75 persons participated in the in-depth interview include 42 men and 33 women. A total of 40 participants took part in the FGDs including ten persons each in all the four LGAs (five males and five females) selected jointly by the opinion leaders and the researchers. The inclusive criteria were that participants must be opinion leader in their localities, must have spent at least 10 years in the area, and an indigene of the community. All participants were paid stipends for their transportation fare and refreshment at the end of each session in line with the promise to motivate them to be part of the exercise. The interviews as well as the FGDs were conducted in English and the corrupted version -pidgin. The study sort such socio-economic/demographic information such as: sex, age, religion, marital status, highest level of education, occupation, monthly income level, level of activity in the Niger Delta struggle and ways of achieving peace and justice in the Niger Delta.

\section{Data Analysis and Ethical Considerations:-}

The data for the study were analyses qualitatively using N6 NUD*IST software after transcription of data and coding and content analyzed in term of the themes and objectives that the study tried to achieve. In analyzing the transcripts from the FGDs, in-depth and key informant interviews, the thematic analysis technique was used to uncover themes and trends. Comments on aspects of the objectives of the study were compared by place of interview. Such excerpts or extracts are the views expressed by the majority of the discussants. These were also supported with similar views from the FGDs and in-depth interviews.

Ethically, approval for this work was given by Centre for Population and Environmental Development Ethical Committee. Though the study was classified as a low risk one in term of the objects of investigation, At all levels, participants were briefed on the study objectives and their consent was received verbally before administering any of the research protocols. In addition, all the participants were informed of their right to withdraw their participation in the study at any stage. The participants were also assured of their anonymity during and after the study (10).

\section{Results and Discussions:-}

\section{Background Information on participants:-}

As indicated in Table 1, the total numbers of participants in the study were 115 participants comprising 75 persons who took part in the in-depth interviews and 40 of them who were in FGDs. Out of the 75 persons that took part in the in-depth interviews, 56\% (42) were male while 44\% (33) were female. The dominant age brackets of the persons interviewed fell within 31-40 and 41-50 years age groups with 21 and 20 persons respectively. Sixty-Four or $85.3 \%$ of the interviewees were married; more of them were from secondary schools in term of their educational background and more of them earning N11, 000-N30, 000 monthly. Regarding the participants in the FGDs as evident in Table 1, equal numbers of them (10) were drawn from all the four LGAs were the study took place with more of them (12) from the age range of 31-40 years. Like the interviewees, a greater proportion of them (36\%) were married with 14 of who had secondary or tertiary education. More of the FGDs participants (18) fell within the income range of person who earned more than N50, 000 compared to 12 of them who earned N11, 000-N30, 000 
Table 1:- Characteristics of study participants for in-depth interviews and FGDs

\begin{tabular}{|c|c|c|c|c|c|c|c|c|}
\hline & \multicolumn{4}{|c|}{ In-depth Interview } & \multicolumn{4}{|c|}{ Focus Group Discussions } \\
\hline & $\begin{array}{l}\text { Brass } \\
\mathrm{N}=18\end{array}$ & $\begin{array}{c}\text { Ekeremor } \\
N=19\end{array}$ & $\begin{array}{c}\text { Sagbama } \\
N=18\end{array}$ & $\begin{array}{c}\text { Southern } \\
\text { Ijaw }=20\end{array}$ & $\begin{array}{l}\text { Brass } \\
N=10\end{array}$ & $\begin{array}{c}\text { Ekeremor } \\
\mathbf{N}=10\end{array}$ & $\begin{array}{c}\text { Sagbama } \\
N=10\end{array}$ & $\begin{array}{c}\text { Southern } \\
\text { Ijaw } N=10\end{array}$ \\
\hline \multicolumn{9}{|l|}{ Sex } \\
\hline male & 10 & 11 & 10 & 11 & 5 & 5 & 5 & 5 \\
\hline Female & 8 & 8 & 8 & 9 & 5 & 5 & 5 & 5 \\
\hline \multicolumn{9}{|l|}{ Age } \\
\hline Less than 20 & 2 & 2 & 0 & 1 & 0 & 1 & 0 & 0 \\
\hline $21-30$ & 3 & 4 & 3 & 5 & 2 & 3 & 2 & 2 \\
\hline $31-40$ & 5 & 5 & 5 & 6 & 3 & 2 & 4 & 3 \\
\hline $41-50$ & 6 & 4 & 6 & 4 & 3 & 3 & 2 & 3 \\
\hline 51and above & 2 & 4 & 4 & 4 & 2 & 1 & 2 & 2 \\
\hline \multicolumn{9}{|l|}{ Marital Status } \\
\hline Married & 15 & 16 & 16 & 17 & 8 & 9 & 10 & 9 \\
\hline Single & 3 & 3 & 2 & 3 & 2 & 1 & 0 & 1 \\
\hline \multicolumn{9}{|c|}{ Highest Level of Education } \\
\hline None & 4 & 3 & 3 & 5 & 0 & 0 & 0 & 0 \\
\hline Primary & 5 & 4 & 5 & 5 & 3 & 3 & 3 & 3 \\
\hline Secondary & 5 & 6 & 7 & 5 & 4 & 3 & 4 & 3 \\
\hline Tertiary & 4 & 6 & 3 & 5 & 3 & 4 & 3 & 4 \\
\hline \multicolumn{9}{|l|}{ Income Per Month } \\
\hline Less than 10,000 & 6 & 7 & 6 & 8 & 1 & 2 & 0 & 1 \\
\hline $11,000-30,000$ & 6 & 8 & 5 & 6 & 3 & 2 & 3 & 4 \\
\hline $31,000-50,000$ & 3 & 3 & 3 & 3 & 2 & 1 & 2 & 1 \\
\hline More than 50,000 & 3 & 1 & 4 & 3 & 4 & 5 & 5 & 4 \\
\hline
\end{tabular}

Indigenous demands for justice and peace:-

The content analysis of the expectations of the people of the studied locations of what will bring about justice and peace; revealed four categorizations of demands namely: (1) Institutional/constitutional Demands (2) Economic/Inclusiveness participation demands. (3) Infrastructural Demands (4) Oil Companies/Federal Government Behavioral Change Demands. Though these are itemized here, there are no clear lines between and among these demands.

\section{Institutional/Constitutional Demands:-}

These demands bother on the constitution of the Federal Republic of Nigeria and the establishment of institutions. According to participants either in the interviews or FGDs, the constitution of the country as it is currently, is so asymmetric and unfair to the people of the Niger Delta. For example, these groups of persons believed that Nigeria is a federated State that is being administered as a unitary entity. According to the persons who hold this view, in other advanced democracy like America which Nigeria patterned her affairs, the units (States) which make up the federation are allowed to develop at their own pace. An excerpt from one of the interview in Sagbama LGA puts this better:

"Make this government of Nigeria just leave the states make them waka according to wetin God give them, make them use wetin God give them as they like instead of this Federal Control"

(The government of Nigeria should allow the States to be. The States should be allowed to use the gift from God to them according to their desires instead of Federal control from the center)

It is apparent that the demand of these groups of persons is that Nigeria is a federated entity and should be so administered through the practice of true federalism; anchored on fiscal federalism and resource control. Put in other words, the persons with this view believed that the people of the Niger Delta States are being robbed perpetually without an end to this exploitation in the name of a "pseudo enclave in Africa called Nigeria". From the belief of these persons, as evident from the interviews and FGDs, the "so-called country" named as Nigeria only exists as a result of the presence of Niger Delta oil; hence, each successive administrations at the federal level become aggressive to anybody in the Niger Delta region who wants to work against the benefits. Extract from an FGD in Twon-Brass give a clearer picture to the above position; 


\begin{abstract}
"Nigeria is calling for peace with this lopsided federalism. How can we have peace in this atmosphere of injustice? Ino go work na (it is impossible). We say we are operating a federal government. What I was taught in my elementary government class was that the small units operate on their own. They are the owners of every mineral wealth in their land. But what do we have in Nigeria. The owners have no say on how to manage their God-given wealth. We need to control our resources for there to be peace. After all, all of us get small small thing wen God take bless our region (After all, every regions are gifted with at least some resources). Let all of us tap and use what belong to us and give taxes to the federal government. But the situation in Nigeria is different because, the owners of the land have no power on how the wealth from their land is distributed. The trend must be reversed, so that we can begin to own and control our God-given blessing"
\end{abstract}

The immediate need of these groups of Niger Deltans is for the region to control the oil found in their region; with taxes being paid to the center government - this thus indicate that, once the Niger Delta States are allowed to control their God bestowed oil wealth, peace will return to the region. These people believed in restructuring of the Nigeria federation; to reflect a true Federal Commonwealth of Nigerian Nationalities or a Confederation of Independent Republics of Nigeria.

Another expectation from the participants in the study that is related to institutional/constitutional demands has to do with state of current legislations as they relate to the operation of the oil companies and the revenue sharing formula of the federal government of Nigeria as enshrined in the 1999 constitution. Many participants both in interviews as well as the FGDs were of the opinion that the constitution of Nigeria in its present form and shape is a rape and gross injustice to the people of the oil bearing states. Infact, they described the laws relating to oil operations as man inhumanity to man and a promotion of what true federalism stands against. For example, some persons held the view that the constitution is soft with oil companies to enhance perpetual subjugations of the owners of the wealth. From their perspective, oil spillages are regular evils enabled by oil companies who always hold on to cries of sabotage from community members in their area of operations; in order to avoid compensation for persons whose lands were polluted by such companies. The position of these participants is that there should be legislations guiding the operations of International Oil Companies (IOCs) especially as it has to do with pollution of environment. According to them, oil companies should know the expectations of the government relating to the environmental impacts of their oil drilling as fully enacted in the constitution and memoranda of understanding relating to their operations and the consequences or failure to comply with the provisions. An excerpt from an interview explicitly clarified this point:

"The laws guiding the operations of oil companies are weak and sometimes there are no provisions to hold these international rascals down to do the needful. There should be legislations embedded in our constitution or any agreement with oil companies for example saying that if you spill a drop of oil in our environment, this is the penalty and failure to carry out the agreement provisions if there is a spill should bring about jail punishments. The constitution or agreements should also contain mode of compensation to the people whose livelihoods have been touched. But I don't think our present constitution can guarantee what I am saying here. The law makers both at the National Assembly and the State Houses must take a deeper look into provisions dealing with the ways International Oil Companies carry out their daily business and their obligations to the state and their immediate communities of operations"

The message by the participants here is that, there should be solid laws regulating the activities and operations of OICs in such a way that they will be liable in the event of the breach of such provisions; especially as it has to do with pollutions from spillages and adequate compensations to affected persons as a portion of this FGD in Ekeremor also indicate: 


\begin{abstract}
"The oil companies know what they are doing. They know our environment more than us. They also know the weakness inherent in our laws. They indirectly get involved in the process of our law making my paying for bills through their friends in either National Assembly or the States. This situation makes it extremely difficult for the law makers to come up with drastic provisions that will check their inimical exploration activities. We need to work on these kinds of legislations that can compel the oil companies to do the right things like dealing with spillages and compensations"
\end{abstract}

The constitutional demand of the persons from the studied locations equally relate to issue with military deployment by the Nigerian Government. By the provision of the constitution, the use of military is mostly related to a war situation or when there is anarchy in parts of the country. However, the situation in the Niger Delta called for some reflections. How does one explain the consistent and an unending deployment of military to most parts of the region of Niger Delta as if the region is experiencing a war? The people believed that, this is abnormal and wrong. They perceived this military occupation as a way of subjugating the advocate of good life for the Niger Delta people. Put differently, most participants in the interviews and FGDs questioned the rational for continuously keeping military personnel in the region. These groups of persons argued that, each time such deployment is done to an area in Nigeria, it comes with a lot of other evils such as sexual harassments, breach of fundamental human rights of the people of such location and without regard to civility - hence, they believed these things have become the everyday experiences of people in the Niger Delta State. As remedy to what they called unjustified military occupation of the South-South territory, they called for demilitarization of the region by reversing the deployment of military personnel into Niger Delta. According to the participants in the study, the presence of military in the region had led to persistent invasion of communities of Niger Delta States. The people frown at a situation where innocent, hardworking Niger Deltans or other Nigerians who live in these locations are terrorized and traumatized by the activities of the force. They requested the government to reverse the trend of military deployment to the Niger Delta region, as this had angered some youth, who have gone on to challenge this perceived injustice and this had produced unintended consequences. Therefore, participants in the study believed that demilitarization of the region, will contribute to the peace in the region as the interview in Southern Ijaw LGA below captured this aptly:

"The Nigeria Federal government they see Niger Delta as trouble makers. Na that one they make them they bring soldiers come fight with our people. As me and you know say, all these soldiers head no reach ground. They go fit do anyhow. Infact, them they do anyhow. Them don kill many innocent people for here. This kind thing they vex our people well well. Na him our youth come provoke-come they fight the soldier. A whole village they fit run enter bush for many days because of the fear when our people they fear make soldiers no kill them. Them don fuck some of our wives, girls na small thing for their hand. Our people come be like say na war we dey for here. This one no good. Make government come take this army comot from our village kpatakpata so that we go get peace. This thing they vex us. They one kill us because of our oil? Make them come remove the soldier when they disturb our normal life"

(The government of Nigeria perceived Niger Deltans as trouble makers. That is responsible for the consistent deployment of army to deal with our people. It is apparent from our knowledge, that, most army personnel are not level headed, they could misbehave. Infact, they are misbehaving. They have killed many innocent people here in our area and this had led to provocation of our people, which led to the fight between our youth and the soldiers. The whole of a village can run into the bush and sleep there for many days for the fear of being killed by soldiers. They have been having sex with some of our wives - girls are understatements in this matter. It is like a war situation in our area here. This is bad. It is imperative that the villages are demilitarized entirely to make way for peace in the Niger Delta. We are angry. The government wants to kill us for the sake of our oil. They should take the soldiers away that have been disturbing our daily lives).

The fight against corruption, while it had been commended by Niger Deltans and other Nigerians, the studied participant did not see the fight as a total fight. To them, it is a fight against the opposition figures and opposition of the ruling party. Besides, the participants also saw the whole thing as laced with ethnic colorations. The federal agencies such as: Economic and Financial Crimes Commission (EFCC) and Independent Corrupt Practices and Other Related Offences Commission (ICPC) are perceived as instruments for beating oppositions into submission. To the studied participants, Niger Delta politicians especially, the men who worked with the immediate past 
president - Dr. Goodluck Ebele Jonathan are the target of these bodies - leaving persons who have more questionable attributes. The interpretation of the groups across the study localities is that, the way politicians from the region of Niger Delta are being followed is again a testimony to the repressive nature of successive governments at the federal level to keep the lips of activists in the region perpetually sealed. The participants described it as the agenda of the Buhari led government. An agenda which they believed had the objective of intimidating the few persons who are still vocal about the struggle for resource control to come to the side of the government. According to them, things that other persons in the North will do without any notice from the federal government easily draw provocations from the agencies of the government such as: the police, the armed forces, ICPC and EFCC. The people are of the view, that the federal government should stop this bias against personalities and politicians from the Niger Delta States and be total in the war against corruption without some sacred cows who hide under the umbrella of the ruling party to enjoy immunities which the constitution of Nigeria do not confer on them. The extract from an interview in Southern Ijaw put more light on this position:

"The oil that we have in our place had turned to become a curse for the owners and it is not good to be identified as a son from an oil community. This government is out to deal with anybody from oil producing area who want to stand against the federal interest. EFCC and ICPC will be your visitors once you speak against the injustice against our people. Meanwhile, people are there from the north that had done terrible things but the government decided to look the other way. Government should treat all of us equally. The harassment against persons from the Niger Delta people is because of the struggle for resource control and this should stop immediately, if the federal government wants peace to reign here in the South-South States"

\section{Economic/Inclusiveness participation demands:-}

A critical examination of the demands for justice and peace by the indigenous people of Niger Delta based on the pronouncements of the participants of the study indicate a serious yearning for economic improvement through adequate participation in the management, ownerships and running of the affairs of their God-given wealth and resources. From their perspective, while this is supposed to be taken for granted, this had not really been the case; since every government at the federal level have willfully tried to create poverty in the region in the means of abundance resources that are found in their territory by robbing the people of their economic interest and excluding them from managing and running the businesses that are associated with the oil industries. It is therefore the position the participants in the study, that the calls for peace in the region will not see the light of the day until justice prevail by taking cognizant of the economic interest of the indigenous people through inclusive policies that recognize ownership of the resources as they relate to the following arguments.

In the first place, the participants frown seriously at the politics of oil blocks. They find it as a huge aberration when over $80 \%$ of the current oil blocks are owned by northern persons who are hundreds of kilometers away from the pollutions of these oil blocks. While they the northern persons who owned the oil blocks are enjoying the wealth and fame that these oil blocks produced, the people in the Niger Delta are left to deal with the consequences of the explorations. In their words, it is very sad to see that behind your house is an oil wells full of petroleum in billions of barrels, yet you go to bed without eating. However, when there are spillages, they run right into your source of drinking waters and your immediate ecosystems and disturb the balance and render them useless. Your sources of livelihood are immediately taken away and further impoverishing the owners. The participants described this as big paradox which can only be resolved by serious or vigorous agitations. According to the participants, the owners are now made to beg for what ordinarily had been given to them by nature. To them, this is unacceptable and calling for peace in this environment while the people are suffering is a huge injustice to the indigenous people. To enjoy peace in the region according to them, the Federal Government must do the needful; by inclusive participation of the people of the Niger Delta in the oil industry and ownership of oil blocs. Thus, the participant demanded that the Federal Government should articulate policies and actions in place that will address the lack of participations, as well as the imbalance in the ownership of oil and gas assets if she requires peace in the region. In a simple form, an FGD in Oporoma summarized this demand.

"The Federal Government and the Oil Companies must put a plan in place to empower the owners of the oil for full and adequate participations in the oil businesses. This involved allocating worthy citizens of the Niger Delta oil blocks like their northern counterparts. If this happens, then we are close to peace, otherwise, they should forget about peace talk or be ready to kill all of us before tapping our oil" 
Another demand relating to the economic interest of the Niger Deltan is in the area of participation in security and oil facility protection. The participants demanded for surveillance and the protection of oil and gas infrastructure as a way to bring about peace and take care of their economic interest. The argument of the participants was hinged on the facts that the indigenous people of the Niger Delta, apart from their ownership of the oil wells, are closer to the locations of the facilities. This, according to them put them at great advantage position to provide surveillance services to the facilities in view of the knowledge of the immediate environment and this benefit of knowing the area equally empowered them to identify anybody who wants to damage the facilities. An extract from an FGD in Ekeremor captured this succinctly:

"Na we go fit watch the pipeline. Na here dey born us and na we know this areas well. We also know ourselves. Any bad person here, when go do bad thing, we still know them. No other people get this plenty advantages like us. This one go also give us money for wetin belong to us"

(We are better place to provide surveillance over the pipelines. We were born here and we have very good knowledge of the terrains. We equally know ourselves very well, to the extent that; we can easily identify anybody with evil intentions. Nobody has these kinds of advantages like us and this will generate income to us at least from our God-given wealth)

The argument here is that, jobs relating to oil facilities surveillance, apart from the fact that their geographical locations placed them (the Niger Deltans) at advantages of doing them very well, it will also take care of their incomes as well as employment and prevent idleness which is common in the region, thereby leading to peace as a result of the engagement of able body men and women.

Another economic /inclusive participation demand was the issue of amnesty. The government of late President Yar'Adua, desirous of peace in the Niger Delta Region as a strategy of boosting oil production, granted the militant in the Niger Delta Amnesty which enabled them to laid down their arms and be forgiven for atrocities committed against the Nigerian State. This program brought about relative peace and achieved the objective for which it was set up. However, the emergence of the civilian regime of President Mohammadu Buhari believed that the program should be reviewed which led to slack in some of the activities. But the Niger Deltans, even though have some reservations about the program, believed it has achieved some laudable objectives of peace and tranquility of the region; hence, the participants in the study pointed at the continuation of amnesty as a panacea for peace in the region. According to them, amnesty needs to be reviewed by re-integrating the ex-militants into civil life through retraining and rehabilitation. The participants believed that amnesty should be restructured with clear exit strategies, so that those in the program must have jobs to return to or be given a fixed amount of money to start up businesses relating to the trade they have learnt. The participants also believed that, unlike the last amnesty program managed by President Goodluck Jonathan, the current scheme should be more inclusive. Infact, the participants advocated for some carefully selected criteria which make the program to cover graduates of higher institutions from the area who were largely excluded in the last scheme and that amnesty should cover major ethnic groups in the region. Furthermore, from the interviews and FGDs, the participants believed that, this round of amnesty should not be an end in itself as was the case in Presidents Yar'Adua and Goodluck Jonathan's case but it should be a time to address the injustice in the region by massive infrastructural construction or rehabilitation. This portion of an interview Twon-Brass captured this very well;

"Amnesty needs to continue and reviewed to include areas that were overlooked, such as inclusion of graduates as well as all the tribes in the region. The scheme must have a clear way to end it. For example, at the end of the exercise, the participants in the scheme must be given jobs based on the skills they have learnt or given money to commence their own businesses based on their skills areas".

Some participants also decried the way the last opportunity of peace provided by amnesty was blown away. According to them, the Federal Government did not make use of the relative peace that amnesty produce to do the needful. Hence, the participants believed that the Federal Government saw amnesty as an end in itself instead of a time to address the numerous infrastructures demands of the people in the Niger Delta as the excerpt below from Ekeremor presents: 


\begin{abstract}
"The federal government of Nigeria did not use the relative peace atmosphere that amnesty ushered in at all. They rested during the implementation of the scheme, thinking - this is the end and that they have been able to pacify the restive youth with the program. Alas, that was one of the deadly assumptions by the regime of Goodluck Jonathan. The government would have used the time to put infrastructures in place and address some of the demands during the widow of peace which the program provided. However, the program was hijacked by the politicians and nothing was done to address the causes of the endless agitations. Therefore, the new program must avoid the trap and use the amnesty period to address the grievances of the people of the Niger Delta. This will yield the needed peace across the tribes in the region.
\end{abstract}

The Economic/Inclusiveness participation demands of the participants in the study also involved the call for economic development and empowerment, which will bring life to the host communities where the IOCs are operating. In the Niger Delta, the paradox of living so close to wealth, yet live in abject poverty had led to the endless unrest in Niger Delta. The participants in the study believed that, the OICs must moved beyond the business of oil extraction and begin to set up sister industries that will process the crude oil and other products. In this way, according to the participants thousands of employments will be created. The people frown at a situation where the oil is just extracted and the revenues are taken to the countries of the IOCs as inimical to the economic aspirations of not only oil producing areas but Nigeria as a whole. Hence, they believed that the Federal Government of Nigeria should come up with policy that changes its oil and gas industry from extractive to domestication and local processing. In their words, "the domestication and setting up of local processing plants will open up the region for employment opportunities and boost the everyday economic life of the region". From the interview, it was also evident that, the participants were concerned about the constant importation of fuel into the country due to bad refineries. They advocated for a bill that will make IOCs to build refineries in area of operations, which will bring about jobs creation for the people of the region. The people reiterated the contributions of joblessness in the production of restive youth, hence, believed that the opening of oil processing industries will create jobs and reduce the restiveness. They applauded the New Nigerian Local content policy - which they see as a way of increasing participation of the indigenous people in the oil industries. The participants called for a review and update of the national gas master plan to integrate the economic interests of the region. For example, the participants believed that as a matter of urgency, the Federal Government should allow the take off the Brass LNG and fertilizer plant project, including the NLNG Train 7 in Bonny.

From the study participants, issues relating to human capital development/training of youth for skill acquisitions and employment were also raised as they concerned rehabilitation, resettlement and rein-integration of victims of Niger Delta struggle. Most of the participants believed that oil companies and to some extent the Federal Government are hiding under the coverage of low capacity of the people of Nigeria Delta to ushered in half -baked so-called experts from abroad and from other ethnic groups to lord it over the good people of the region. The indigenous people perceived this as unacceptable and required to be addressed as a matter of urgent national importance. They see it as a lie that the youth from the region do not have the requisite knowledge to work in the oil industries. According to them, unlike in the past, the story is different with a good number of youth who have been trained locally and at internationally level to compete favorably with their counterparts from anywhere in the oil industries. They are of the opinion, that even if such youth do not have what it takes, they are willing to learn new skills which will enable them to fit into the industries - believing, the case of these people is different, having championed the need for the oil company and the Federal Government to think more positively about the people of the region. Besides, the companies are tapping resources which belong to the people of the region; hence, it is imperative that these people be given priorities over any other persons. A section of the participants believed that, there should be deliberate efforts to set up human capital development mechanism for the youth of the region by setting up skills acquisition centers and giving employment to deserving youth from Niger Delta. The participant detest situations where other ethnic groups like the Yorubas, Ibos and Hausas take up jobs from the youth in the oil producing communities and give such jobs to their brothers not because they are better qualified but on the ground of nepotism and favoritism. While appreciating the fact Nigeria in one country, they are however unhappy with the people from the major ethnic groups from Nigeria who take what rightly belong to them and give it to their relatives. The participants see these kinds of scenarios as fertile receipts for anarchy and restiveness; and for peace to reign in the region such practice of injustice must be addressed. 


\section{Infrastructural Demands:-}

The demand for infrastructure development for Niger Delta States and oil producing communities was pervasive in the study. Participants hold the belief that, as the hen laying the eggs with which other parts of the countries including the Federal Capital Territory derived their beauty, the region ought to get better attentions than the successive governments at the federal level often give to it. They advocated for infrastructures development master plan for the Niger Delta, which should be put in place with alacrity and given a schedule for full implementation by the Federal Government as well as IOCs as an excerpt in an FGD in Sagbama LGA captured this below.

"Na we get the oil, so the governments need to give us better road before any other area. Make government do this one sharp sharp with better better plan when go make us happy"

(We owned the oil; hence the government should give us better roads before any other area in Nigeria. This must be done quickly and a plan put in place to achieve this and make us happy)

The interrogations as to the type of desired infrastructure to be put in place came with such answers such as: good network of roads as seen in Abuja and other developed nations. Specifically, the East-West road was mentioned as an example of the road needed. Study participants argued that, what they have now is an improvement from what it used to be, but the Federal Government must strive harder to bring the road to world class standards. Apart from the East-West Road, the participants questioned the rational of the exclusion of Niger Delta from completion of railways construction in Nigeria. In this regards, the people requested for a railway to run through the heart of the Niger Delta States to Lagos using modern facilities of double gauge rails.

Additionally, the participants believed that the Federal Government should continue in their effort to build a maritime university in Gbaramatu Kingdom. They believed the continuation of the building of this university is crucial to the peace effort since the stoppage of work was politically motivated by certain politicians who believed they want to control the affairs of the Federal Government to serve their narrow motives. Apart from road and railways, the participants were of opinion that the waterways should also be developed to open up the communities in the coastal regions for effective economic activities. Other infrastructural facilities requested include, good water works, state of the arts hospitals and power plants to generate electricity to the communities in the region jointly funded by the Federal Government and the IOCs as seen from the extract in an interview in Oporoma below;

"As an Ijaw man, what happens to one person happens to all. Look at Delta State. The only thing that Goodluck Jonathan remembered to do for his people - the Maritime University is about to be remove, and the government is calling for peace? It will not happen. They should return that University and I know my brothers here in Bayelsa will attend that school. What they are doing is politics by one man who is bigger than all of us. But we will resist him with everything until the school is return to us"

\section{Oil Companies/Federal Government Behavioral Change Demands:-}

The participants in the study are not happy with the Federal Government (FG) and IOCs. They perceived a form alliance between the FG and the oil companies to short-change the people of the region based on the kind of attitudes toward the people of the region. The first vested issue relates to the behavior of IOCs in terms of location of their operation headquarters. According to the participants, the IOCs pollute the environment of the Niger Delta and carry their base of operations to a State that had no bearing to their activities. For example, they pointed out that even when all the oil wells where the IOCs derived their benefits are located in the hearts of Niger Delta State, most of the headquarters are based in Lagos, Lagos State, where the companies pay huge taxes and employed their indigenes to the detriments of the citizens of their operational base. The participants believed this gross injustice to the people of Niger Delta and called for the relocation of IOCs headquarters and their administrative and operational headquarters to the Niger Delta region. In discussing the demand for the relocation of the headquarters to their base of operation, the participants lamented the collaboration of the FG with the companies which persistently rob the people of the region of their wealth as the statement from an interview below from Ekeremor LGA make this point more explicit. 
"I do not blame the oil companies but the federal government who seemed to be having an alliance with them. When the oil companies came to Nigeria, they were hosted in Lagos when our capital was still there. Nobody told them that there were what we called host communities. They were just informed that there are oil wells for them to explore and later to drill for well. The bargain was made for the commitment of these companies in terms of royalties. Agreements were made and memoranda of understanding were prepared with both the federal government and the representatives of such companies signing. Infact the communities were not part of the negotiations and were not considered in the scheme of the discussions. The oil companies came to the region and started their business without the host knowing the consequences of the activities they were involved. The community elders and leaders were more than happy to see the visitors in their land, coming with new items that were never part of their lives. Time had passed. We know better now - in term of benefits and the consequences of the actions of the companies. Regrettably, even with our knowledge, the oil companies want the status quo to stay. There came a struggle to reverse the trend to take care of the communities in the negotiation but agreements have been drawn as the foreigners know the level of our corruptions and have invaded our law making outfits using their local collaborators to turn things in their favor. Therefore, the status quo remained. Groaning under the hardship of the operations of the companies, the communities commenced a struggle of hostility which later metamorphosed into armed struggles and eventually made the region inaccessible to the oil magnates - who are now asking for peace without a reversal of the old agreements. New agreement must be signed that respect the expectations of the oil owners. These must be change before peace can be restored to the region"

The statement above, points to a major reason why things are what they are in the oil bearing states. If the people from the oil bearing states were in the negotiations that produced the agreements, right from the beginning, all their concerns would have been built into the documents. However, this was not the situation, leaving oil companies to do what is within their expectations and see themselves as favoring the communities who were supposed to be the owners of the oil in question. Hence, there is need to change the existing laws to take cognizant of the community ownership of the oil resources.

The change of attitude by IOCs and FG from the views of participants should come in the way the issues of pollution of environment and oil spillages are handled. Most participants believed that the attitude of oil companies who always believed every spillage from their pipes is an act of sabotage must stop forthwith and FG must put policy in place to address the arrogance of these IOCs. The government should put policies and legislate on how an act of spillage or other pollutions must be dealt with. The participants argued that penalty for pollutions must be spelt out and compensation mechanisms for people and affected communities put in place. In a nutshell, they advocated for a sustainable compensation plan for people of Niger Delta in term of the amount of pollution since the inception of the exploration activities from Oloibiri, in Bayelsa State. A interviewee from Southern Ijaw LGA had this to say about the issue of pollution and compensation that is desired in the Niger Delta.

"Let me start by saying that we have limited knowledge in this subject compared to the oil companies, therefore evaluating them becomes difficult. However, we read in papers and internet what is obtained in other places where the same, I mean the same oil companies here are operating. In the first place, they use standard equipment for their works to avoid spillages and if this does happens like it does sometimes, they - the companies have limited time to make sure such clear up is effected within weeks and not in a month. In the Niger Delta where decades of oil exploration had destroyed our ecosystem, nothing has been done to clean the land like the polluted land of Ogoni. What is responsible, it is the attitude of our government to the oil companies. If a spillage happens in most advanced countries, the oil companies know the kind of sanction (s) that will come from the government and are compared to quickly move to address the issue. Here in Nigeria, our governments do not have the capabilities to hold defaulting powerful oil companies to book, due to the compromise of the officials at certain quarters and the weakness of our regulations and doing this is crucial to bringing peace to the Niger Delta as this will bring about cleaning of spillages and compensating appropriate communities and persons and avoiding the wraths of such locations and thereby promote peace”. 
From the point of view of the statement above, while addressing issue of spillages and compensations is necessary to achieve peace in the Niger Delta, the ability in term of knowledge of the issue by persons in the region is relatively limited compared to their counterparts overseas. The swiftness to which oil companies in advanced countries respond to spillages and issue of compensations is higher than what is obtained here in Nigeria. Two things are noticeable here. The first has to do with the attitude of our government and secondly, the kinds of policy we have in place to deal with the pollution and compensation. Hence, the participants believed that the government as well as the oil companies must change their attitudes on the issues of environmental pollution. For example, the participants believed that a way of dodging their responsibilities to the people of the Niger Delta in the event of oil spillage is to cry to the roof top by oil companies that there was a sabotage inpites of the pipelines that have been used for decades without maintenance. To compound the problem, from the perspective of the participants, the government agencies that were supposed to hold these companies accountable had formed an unholy alliance with the IOCs and subsequently, the Niger Delta region is left without someone to lift this burden, and eventual resort to taking the laws into their hands to address the issue. Therefore, to achieve peace in the region, one thing the oil companies must do is a change of attitude to address spillages and compensations in a timely manner as a way of promoting peace.

Like the IOCs, the FG of Nigeria according to the participants in the study, lack commitment in addressing the Niger Delta question without which peace will be elusive in the region. The people in the study believed that the commitment from the Federal Government to sincerely address the Niger Delta question is critical to returning to the path of peace. However, they accused the government of half-hearted political solutions which brought ineffective solutions to the Niger Delta crisis, since the interests of the people of the Niger Delta were not protected. Every agency set to alleviate the plight of the people like OMPADEC, NDDC, Ministry of Niger Delta, Amnesty program and $13 \%$ derivation principle, did not bring about development to the people, hence the people in the study called for adequate funding of federal agencies in the region. Furthermore, the Federal Government should compensate communities that were destroyed in the course of the Niger Delta Struggle like Odi for genuine indication of reconciliation, however, successive government have only paid lip services to the development of the region. For example, the participants believed that, a bulk of what is meant to fund the NDDC and the Amnesty program are still being withheld and being manipulated at the detriment of the indigenous people. The consequence is that the impacts of these agencies are not felt by the ordinary persons in the regions whose suffering had continued, hence, the agitation continued too. Therefore, a receipt for peace is for the Federal Government to turn a new leaf concerning the activities of the region and get more committed to deal with the several development challenges as a way of promoting peace in the region.

\section{Conclusion and Recommendations:-}

The opinions of the people of the Niger Delta as ways for achieving justice and enduring peace in the region are the focus of the study. From the analyses of the interviews and FGDs, four demands were put forward by the people of the region as panacea for lasting peace in the region: Firstly, people believed that Nigeria should truly be administered as a federated unit where the practice of true federalism; anchored on true fiscal federalism and resource control is the norm as enshrined in the country's constitution. Secondly, the people requested for economic improvement through adequate participation in the management, ownerships and running of the affairs of their Godgiven wealth such as ownership of oil blocks and other oil resources. Thirdly, the expectation of the people in the region is to see to a massive provision of infrastructures including roads, rehabilitation of water water-ways, construction of railways, building of power plants among others. Lastly, the region called for a change of attitude by Federal Government as well as the International Oil Companies to take issues relating the Niger Delta more serious by showing a greater level of commitments in addressing developmental challenges and issues such as pollution.

It is the recommendation of this paper that these demands of the people be taken seriously and the Federal Government working with the IOCs should immediately put action plan in place in addressing the demands of the people of Niger Delta. Today, what we have is Niger Delta Avenger, as a writer once put it, "there would be a recurring cycle of militancy in the Niger Delta region long after the fury of Niger Delta Avengers may have been assuaged through the ongoing negotiations by the Presidency". For lasting solution, there is need for rigorous stakeholders meetings and workshops to articulate the demands of the people and bullet point's actions and genuine desire to implement the outlined actions if the perennial agitations in the region are to be something of the past. 


\section{Acknowledgements:-}

This publication as well as the research leading to the publication was sponsored by the Think Tank Initiative (TTI) of IDRC, Canada and Centre for Populations and Environmental Development Benin City, Nigeria. The authors are grateful for the continuous support.

\section{References:-}

1. Agbegbedia, O. A. (2014). Gender Mainstreaming and the Impacts of the Federal Government Amnesty Programme in the Niger Delta Region. International Journal of Gender and Women's Studies, Vol. 2(2); 177195

2. Aghedo, I. (2013). Winning the War, Losing the Peace: Amnesty and the Challenges of Post-Conflict PeaceBuilding in the Niger Delta, Nigeria. Journal of Asian and African Studies 48:267

3. Akinwale, A.A (2010). Amnesty and human capital development agenda for the Niger Delta. Journal of African Studies and Development. Vol 2(8), pp201-207

4. Amaize et al (2016). Niger Delta wants to control its resources. The Vanguard 10 June, http://www.vanguardngr.com/2016/06/n-delta-wants-control-resources-avengers/Accessed 10/6/2016. Accessed 21/06/2016

5. Aminu, S.A. (2013). The Militancy in the Oil Rich Niger Delta: Failure of the Federal Government of Nigeria. Interdisciplinary Journal of Contemporary Research in Business. Vol.4 No. 11 p 813-827

6. Atumah, S. (2015). Beyond the Niger Delta Amnesty. The Vanguard, 1 Augusthttp://www.vanguardngr.com/2015/08/beyond-the-niger-delta-amnesty/Retrieved March 12/03/2015.

7. Ering, S.O, Bassey, G.E \&Odike, E.L. (2013). The Niger Crisis in Nigeria: Pre and Post Amnesty Situation. Mediterranean Journal of Social Science. Vol 4 No. 6 p 421-427

8. Ibude, S.E. (2011). An Evaluation of the Presidential Amnesty Programme for the Niger delta Militants in Nigeria; Implications for Peace and Hydro- Carbon Production in the Oil- Rich Region. A Research Proposal Presented to the Department of Political Science and Public Administration, University of Benin, Benin City.

9. Ikelegbe, A. (2010). Oil, Resource Conflict and the Post Conflict Transition in the Niger Delta Accessed $21 / 06 / 201$

10. Jack-Akhigbe, O.K (2013). The state and Development Interventions in the Niger Delta region of Nigeria. International Journal of Humanities and Social and Science. Vol. 3 No 10

11. Nwankwo, B.O (2015). The Politics of Conflict over Oil in the Niger Delta Region of Nigeria: A Review of the Corporate Responsibility Strategies of the Oil Companies. America Journal of Educational Research, 3 (4) pp 383-392

12. Okonta, I. (2013). Nigeria: Policy incoherence and Challenges of Energy Security. Handbook of Global Energy Policy

13. Omuta, G.E.D (2014). Transforming to Sustainable Development and a Green Economy in the Niger Delta of Nigeria: Challenges and Prospects. CPED Monograph Series No. 9

14. Tonwe, D.A \&Aghedo, I. (2013). Amnesty for Sustainable Peace and Development in Nigeria's Niger Delta region. Panacea or Palliative? Journal of Sustainable Development in Africa. Vol. 15, No.5-6, 